\title{
O jakim artyficjalizmie mówi się w ramach koncepcji epistemicznych układów odniesienia? Polemika z Dariuszem Saganem
}

Korzystając z okazji, jaką jest polemika z Dariuszem Saganem, pozwolę sobie raz jeszcze przypomnieć zasadniczy cel moich publikacji poświęconych epistemicznym układom odniesienia. Są one niczym więcej niż próbą uporządkowania rozproszonych $\mathrm{w}$ wielu tekstach uwag i pomysłów twórcy tego podejścia - Kazimierza Jodkowskiego. (Moje publikacje nawiązują również do tekstów Dariusza Sagana i Piotra Bylicy i w bardzo obszerny sposób nawiązują do bardzo obszernego dorobku Zielonogórskiej Grupy Lokalnej „Nauka a Religia”.) I właśnie dlatego, odpowiadając na niektóre uwagi Sagana, zmuszony będę odpowiadać również na niektóre jego wypowiedzi, które skierowane są do Jodkowskiego.

Sagan zauważa, że

w publikacjach Jodkowskiego rozważania na temat epistemicznych układów odniesienia [EUO] prowadzone są na dość ogólnym poziomie. ${ }^{1}$

Dr hab. Krzysztof J. Kilian, Prof. UZ - Uniwersytet Zielonogórski, e-mail: kiliankrzysztof @yahoo.pl.

(C) Copyright by Krzysztof J. Kilian \& Filozoficzne Aspekty Genezy.

${ }^{1}$ Dariusz SAGAN, „Jaki «artyficjalizm» stanowi epistemiczny układ odniesienia nauki”, Filozoficzne Aspekty Genezy 2018, s. 224 [223-250], https://cutt.ly/AyRn4S (19.05.2019). 
Jodkowski, jak powszechnie wiadomo, w szeregu swoich publikacji zajmuje się studiami przypadków (case studies). A nie zawsze jest tak, że konkretne studium przypadku poparte jest wprzódy szczegółowo opracowaną podbudową teoretyczną, gotowym wzorcem, w który wtłacza się badaną rzeczywistość. Aby to sobie unaocznić, wystarczy przypomnieć sobie Kuhnowskie prace Przewrót kopernikański i Struktura rewolucji naukowych. Gdy pierwszą czyta się przez pryzmat drugiej, bez trudu odnajdujemy w pierwszej paradygmaty, rewolucje naukowe, anomalie, łamigłówki i cała gamę innych Kuhnowskich kategorii.

Zdarza się i tak, że studium przypadku subtelnie wprowadza rozmaite kategorie interpretacyjne, czego przykładem jest artykuł Feyerabenda „Wyjaśnianie, redukcja i empiryzm", w którym pojawia się na przykład kategoria niewspółmierności od razu zastosowana do konkretnego przypadku. Ten konkretny przypadek wymagał odsłonięcia płaszczyzn ontologicznej i językowej niewspółmierności teorii naukowych. W innych pracach Feyerabenda, by trzymać się jednego przykładu, akcentowane są również inne płaszczyzny niewspółmierności (na przykład we wszystkich wydaniach Against Method mówi się o niewspółmierności metodologicznej i obserwacyjnej, obok już wspomnianych płaszczyzn).

Znakomita większość prac Jodkowskiego poświęconych EUO pisanych jest w ten drugi sposób, który przedstawić można tak: jeśli do wyjaśnienia badanego stanu rzeczy potrzebna jest nowa kategoria, to jest wprowadzana $\mathrm{i}$ to $\mathrm{w}$ takim wymiarze, jaki niezbędny jest do wyjaśnienia tego stanu rzeczy. Wprowadzane tym sposobem kategorie „pączkują” wraz z nowymi tekstami, w których są przedstawiane.

Ma to swoje wady i zalety. Zaletą jest to, że nie gubi się z oczu badanego problemu, który nie jest przesłaniany siatką teoretycznych pojęć. Wadą, że szeregu informacji na temat nowowprowadzanych kategorii szukać trzeba w różnych wypowiedziach, zawartych nie tylko w jednym tekście, ale też często rozproszonych w różnych tekstach. Gdyby zatem do zrekonstruowania koncepcji EUO nie była potrzebna analiza rozproszonych pomysłów Jodkowskiego, to moje opracowanie nie miałoby większego sensu, gdyż wszystko, co istotne, dostępne byłoby w jednym jego tekście. Wspomnieć też tu należy o jeszcze jednej kwestii. Koncepcja EUO jest i była dyskutowana na wielu naszych seminariach, w trakcie których zarówno Jodkowski, jak i my niejednokrotnie mieliśmy w tej 
sprawie coś nowego do powiedzenia czy choćby uzupełnialiśmy i komentowaliśmy pomysły, które zrodziły się wcześniej.

Sagan jest również przekonany, że

bardziej szczegółowego omówienia tej koncepcji podjął się inny filozof nauki z Uniwersytetu Zielonogórskiego, Krzysztof J. Kilian. Ten ostatni wyniki swoich analiz przedstawił w postaci siedmiu artykułów opublikowanych na łamach Filozoficznych Aspektów Genezy. ${ }^{2}$

Mocno wątpię w to, że w jakiś szczególnie rzucający się w oczy sposób bardziej szczegółowo od Kazimierza Jodkowskiego omówiłem jego koncepcję. Porządkując to podejście, pouzupełniałem je kilkoma pomysłami, które pojawiły się w trakcie naszych (Jodkowskiego, Bylicy, Sagana i Kiliana) wspólnych, seminaryjnych, mailowych i konferencyjnych (na przykład Wrocław 2016, Poznań 2018) dyskusji.

Przykładowo pomysł z odróżnianiem mocnych i słabych warunków sine qua non zrodził się na jednym z seminariów przy okazji dyskusji nad definicją EUO jako „szereg[u] najogólniejszych założeń, jak można i jak nie można uprawiać nauki". ${ }^{3}$ Ja przekonany jestem, że choćby z czysto pragmatycznych powodów lepiej mówić o najbardziej elementarnych założeniach, by nie wikłać się w poszukiwania kryteriów, za pomocą których rozstrzygać się będzie o, mniejszej lub większej, ogólności poszczególnych założeń. Inny pomysł, dotyczący nośników EUO, jest efektem zarzutu (nie pamiętam czyjego, ale najprawdopodobniej kogoś, kto nie uczestniczył w naszych seminariach), że nie wskazuje się na różnice między EUO a paradygmatami (w Kuhnowskim sensie) czy (Lakatosowskimi) programami badawczymi.

Sagan uważa, że

wyróżnić można trzy epistemiczne układy odniesienia, czyli trzy odmienne ujęcia tego, czym jest nauka w najogólniejszym sensie tego słowa: naturalizm metodologiczny, nadnaturalizm $\mathrm{i}$ artyficjalizm. ${ }^{4}$

\footnotetext{
${ }^{2}$ SAGAN, „Jaki «artyficjalizm»...”, s. 224.

${ }^{3}$ Kazimierz Jodkowski, „Nienaukowy fundament nauki”, w: Zbigniew PIetrZaK (red.), Granice nauki, Lectiones \& Acroases Philosophicae 2013, t. VI, nr 1, s. 96 [59-108].

${ }^{4}$ SAGAN, ,Jaki «artyficjalizm»...”, s. 225.
} 
Ujęcie to jest jednak nazbyt wąskie. Jodkowski mówi o czterech EUO: naturalizmie antynadnaturalistycznym, naturalizmie antyartyficjalistycznym, nadnaturalizmie i artyficjalizmie. Ja, zainspirowany pomysłem Piotra Bylicy, utrzymuję, że istnieje jeszcze jedna taka kategoria: naturalistyczno-teistyczny EUO. Ponadto opisywane przez Jodkowskiego i Bylicę EUO dotyczą wyłącznie współczesnego rozumienia naukowości. Nawet bez wdawania się w (jałowe) spory, kiedy narodziła się nauka, przyznać można, że przed tym współczesnym (od 1859 roku - Darwin, On the Origin of Species) funkcjonowało też jakieś inne rozumienie naukowości. A jeśli takie rozumienie było, to funkcjonowały też inne, od wymienionych już, EUO. Rozstrzygniecie, ile EUO funkcjonowało w nauce, wymaga jeszcze szeregu badań. Przedwczesne jest zatem rozstrzyganie w tej chwili, ile EUO da się wyróżnić.

Sagan moją definicję artyficjalistycznego EUO opatruje kilkoma komentarzami, z których nie wszystkie wyrażają moje intencje:

Artyficjalistyczny EUO to „nakaz dopuszczania w badaniach naukowych obok przyczyn naturalnych również przyczyn sztucznych, inteligentnych". Ta zwięzła definicja [Kiliana] trafia w samo sedno. W artyficjalizmie jako EUO całej nauki, nie tylko teorii inteligentnego projektu, nie chodzi o to, żeby odwołania do przyczyn inteligentnych były konieczne w rozmaitych dyscyplinach naukowych, łącznie z biologią i kosmologią, ale aby przyczyny takie stanowily uprawnione środki eksplanacyjne w nauce, niezależnie od tego, w jakiej dyscyplinie odwołanie do nich może okazać się potrzebne, $\mathrm{i}$ bez względu na to, czy teoria inteligentnego projektu ma jakichkolwiek zwolenników. W takim rozumieniu artyficjalizm mógłby obowiązywać w nauce nawet wówczas, gdyby powszechnie sądzono, że teoria inteligentnego projektu jest fałszywa. ${ }^{5}$

Rozpocznę od ostatniego zdania wypowiedzi Sagana. Tak rozumiany artyficjalizm nie tylko mógłby obowiązywać w nauce, ale i obowiązuje, na przykład w archeologii, na co, nawiasem mówiąc, w kilku swoich publikacjach zwraca uwagę sam Sagan.

Nadmienię też, że o ile mówienie, iż teoria jest prawdziwa (albo teoria jest fałszywa) nie jest wyłącznie, jak przypuszczam, façon de parler, to prowadzi do poważnych trudności, dotyczących wskazania, co, przy takim ujęciu, jest nośnikiem prawdy.

\footnotetext{
${ }^{5}$ SAGAN, ,Jaki «artyficjalizm»...”, s. 230.
} 
Jeśli w przedostatnim zdaniu Sagan nie przedstawia swojego punktu widzenia, to nie przedstawia też mojego. Ja nie pojmuję artyficjalizmu jako punktu widzenia, który „na wszelki wypadek” dopuszcza wyjaśnianie za pomocą przyczyn inteligentnych. W niektórych przypadkach należy takie wyjaśnienia dopuszczać, bo istnieją racje na rzecz takich wyjaśnień.

Sagan trafnie zauważa, że

Teoria ta [ID] nie jest więc tożsama z artyficjalizmem, lecz stanowi co najwyżej jego konkretniejszy przejaw. Kilian zdaje się to dostrzegać przynajmniej w jednej ze swoich wypowiedzi: „Artyficjalistyczny EUO ma swoja egzemplifikacje w teorii inteligentnego projektu". ${ }^{6}$

Utożsamianie ID z artyficjalizmem to błąd kategorialny. ID, gdy rozumiana jest jako alternatywa dla darwinowskiego ewolucjonizmu, jest teorią pochodzenia życia. Artyficjalizm zaś jest zbiorczą nazwą dla dwóch założeń, mocnych warunków sine qua non, tworzących decyzje metodologiczne dopuszczające w nauce wyjaśnienia za pomocą przyczyn naturalnych i sztucznych. Decyzje metodologiczne, o ile nie pojmuje się teorii naukowej restrykcyjnie, jedynie wchodzą w skład tej ostatniej. Zamieszania można łatwo uniknąć, traktując ID jako paradygmat (macierz dyscyplinarną), a decyzje metodologiczne jako składniki jednego z elementów tej macierzy (wartości). Nawiasem mówiąc, teoretycy projektu preferują mówienie o programach badawczych — przy takim stanie rzeczy w odniesieniu do decyzji metodologicznych należałoby mówić o podstawowych sądach wartościujących.

Dodam w tym miejscu, że istotnym novum koncepcji EUO jest właśnie to, że pozwala wyraźnie oddzielić te niewielkie, dwu- lub trzyelementowe zbiory decyzji metodologicznych od szerszych struktur, za pomocą których wyjaśnia się rozwój nauki. Identyczne EUO mogą być składnikami różnych paradygmatów. Przykładowo, wymierzony zarówno w nadnaturalizm, jak i artyficjalizm, naturalistyczny EUO jest składnikiem szczególnej teorii względności i teorii przerywanej równowagi.

Sagan wydaje się przekonany, że nazwie „artyficjalizm” nadaję też jakieś inne znaczenie niż to, które zaproponowałem w definicji:

\footnotetext{
${ }^{6}$ SAGAN, „Jaki «artyficjalizm»...”, s. 230-231.
} 
Kilian korzysta jednak również ze sposobu, w jaki terminem ,artyficjalizm” posługuje się Jodkowski, przez co de facto używa go w dwóch znaczeniach: jako EUO całej nauki i jako EUO tylko teorii inteligentnego projektu. To drugie rozumienie widoczne jest na przykład w [jego] następując[ej] wypowiedzi [...]: „zgodnie z artyficjalizmem niektóre cechy świata ożywionego wskazują, że są efektem ingerencji inteligentnego projektanta, gdyż nie mogły powstać w sposób naturalny". ?

to, że Kilian używa terminu „artyficjalizm” w dwóch znaczeniach, może być jednak nadinterpretacją. ${ }^{8}$

Przeważnie, a dokładniej rzecz biorąc, nieomal zawsze odnoszę artyficjalistyczny EUO do ID z jednego, zasadniczego i podkreślanego w moich tekstach powodu. Spór o dopuszczalność wyjaśnień odwołujących się do przyczyn inteligentnych prowadzony jest obecnie de facto wyłącznie na gruncie nauk o pochodzeniu życia. Nie wiem, jak Sagan rozumie ujęcie Jodkowskiego, że robi z tego jakiś problem. W mojej opinii koncepcja Jodkowskiego jest opisem tego, co faktycznie robi się w nauce, wzbogaconym o szereg wyjaśnień, dlaczego postępuje się tak, a nie inaczej. Ponadto nie używam tej nazwy w dwóch znaczeniach, tylko traktuję artyficjalizm (oraz nadnaturalizm, naturalizmy antyartyficjalistyczny, nadnaturalistyczny i teistyczny) jako EUO (zbiory decyzji metodologicznych), które mogą być składnikami różnych paradygmatów.

Sagan dostrzega też inną trudność, która powstaje wraz z moimi próbami uporządkowania koncepcji EUO:

Wątpliwości wiążą się tutaj z uznaniem przez Kiliana, że każde EUO ma swoje „twarde jądro". Owe twarde jądra to ,takie metafizyczne tezy [...], z których ich zwolennicy nigdy nie zrezygnują, bowiem ich porzucenie byłoby tożsame z zanegowaniem podstawowych założeń, na których bazują EUO”. W przypadku artyficjalizmu jego twardym jądrem ma być teza, zgodnie z którą ,obok przypadku i konieczności w bezpośredni sposób w przyrodzie działają również inteligentne przyczyny". ${ }^{9}$

Decyzje metodologiczne - na co powszechnie zwracano uwagę przynajmniej od początków ubiegłego stulecia i co ja również powtarzałem (opatrując to stosownymi odnośnikami) w swoich tekstach, by ktoś nie posądził mnie o to,

\footnotetext{
${ }^{7}$ SAGAN, „Jaki «artyficjalizm»...”, s. 231.

${ }^{8}$ SAGAN, ,Jaki «artyficjalizm»...”, s. 232.

${ }^{9}$ SAGAN, ,Jaki «artyficjalizm»...”, s. 232.
} 
że jestem przekonany, iż odkryłem coś nowego — zawsze mają swoją podbudowę w metafizycznych tezach, mówiących o tym, co istnieje. Powszechnie wiadomo, że najpierw zakłada się, co istnieje, a dopiero później poszukuje się środków, za pomocą których wykryć można owe byty.

Zaproponowana przeze mnie definicja artyficjalizmu, jak widzi sprawę Sagan, ma być nieadekwatna, bo niezgodna z tym, jak należy postępować w nauce:

Skoro twardym jądrem artyficjalizmu ma być metafizyczna (ontologiczna) teza, że przyczyny inteligentne (różne od ludzi, bo o takie przyczyny inteligentne toczy się spór) „działają” w świecie przyrody, to przywołana na początku tej części artykułu definicja artyficjalizmu jako nakazu „dopuszczania” odwołań do przyczyn inteligentnych w wyjaśnieniach naukowych traci na znaczeniu. Okazuje się teraz, że mają być one nie tylko „dopuszczalne”, ale i rzeczywiście „należy” się na nie (przynajmniej niekiedy) powoływać. ${ }^{10}$

Przyznam, że nie rozumiem, co jest problemem w tym ostatnim zdaniu. Odwołania do przyczyn sztucznych mają być dopuszczalne, bo założono, że takie przyczyny działają w przyrodzie i przynajmniej niekiedy, czyli wtedy, gdy istnieje po temu dobry powód (mówi o tym warunek Jodkowskiego), należy się na nie powołać. Zaś moja definicja artyficjalizmu „traci na znaczeniu” wyłącznie wtedy, gdy pominie się metafizyczne założenia tkwiące u podstaw artyficjalistycznego EUO. To jednak prowadzi w stronę bardzo trudnej do utrzymania wizji rozwoju nauki, za którą, o czym jestem przekonany, optuje Sagan (do tego problemu jeszcze powrócę).

Następująca wypowiedź Sagana nie brzmi jasno:

Jak już wyżej wspominałem, dla teoretyków projektu powoływanie się na przyczyny inteligentne jest koniecznością (w przeciwnym razie nie byliby zwolennikami teorii inteligentnego projektu), dlaczego jednak miałoby to odnosić się do wszystkich naukowców? Mogłoby to mieć jakiś sens, gdyby powszechnie uznawano, że teoria inteligentnego projektu jest słuszna. ${ }^{11}$

i dlatego prowadzi do kilku problemów.

\footnotetext{
${ }^{10}$ SAGAN, „Jaki «artyficjalizm»...”, s. 232.

${ }^{11}$ SAGAN, ,Jaki «artyficjalizm»...”, s. 232.
} 
Nie wiem, co pod szyldem ID rozumie Sagan, gdyż w swoich licznych publikacjach analizuje różne aspekty tego ujęcia. Najczęściej, o ile tym razem to ja nie dokonuję nadinterpretacji jego ujęcia, ma na myśli problem pochodzenia życia. Jeśli się mylę, to skorzystam z okazji, by raz jeszcze podkreślić, że tak właśnie ID pojmuję ja w swoich tekstach. Inaczej to wyrażając, w moich, opublikowanych na łamach Filozoficznych Aspektów Genezy, rozprawach zawsze chodzi mi to ten właśnie wariant teorii ID.

Nie do końca rozumiem też zdanie, w którym stwierdza się, że „dla teoretyków projektu powoływanie się na przyczyny inteligentne jest koniecznością". Rozumiałbym je gdyby brzmiało tak: dla teoretyków projektu, w niektórych, szczegółowo przez nich opisywanych okolicznościach, powoływanie się na przyczyny inteligentne jest koniecznością.

Nie zawsze bowiem zachodzi taka konieczność. Jeśli ID ma się stać programem badawczym, który będzie $\mathrm{w}$ stanie stawić czoła tradycyjnym podejściom ewolucyjnym, to program ten wiele faktów, o których mówią ujęcia tradycyjne, wyjaśniał będzie całkowicie naturalistycznie, gdyż, w wielu takich przypadkach (na przykład partenogeneza), nie będzie potrzeby wprowadzania wyjaśnień artyficjalistycznych. Nie jest zatem koniecznością permanentne powoływanie się na przyczyny sztuczne ani przez teoretyków projektu, ani, tym bardziej, przez wszystkich naukowców. W niektórych sytuacjach, które nota bene szczegółowo opisuje Sagan w swoich publikacjach, takie wyjaśnienia, jak przekonują teoretycy projektu, należy dopuszczać.

Przyznam, że nie rozumiem następującej wypowiedzi Sagana:

Jednak również w takim wypadku [to jest gdyby powszechnie uznawano, że teoria inteligentnego projektu jest słuszna] nie należałoby całkowicie zakazywać naukowcom poszukiwania naturalistycznych wyjaśnień dla zjawisk przyrodniczych, które powszechnie uznawano by w danym czasie za zaprojektowane. Z kolei próba odgórnego narzucenia konieczności powoływania się na przyczyny inteligentne jako wyjściowego założenia całej nauki, niezależnie od sukcesu teorii inteligentnego projektu, nie miałaby dobrego uzasadnienia. ${ }^{12}$

i stąd się biorą moje poniższe wątpliwości.

\footnotetext{
${ }^{12}$ SAGAN, „Jaki «artyficjalizm»...”, s. 232.
} 
Pojawia się tu pytanie, kto miałby taki zakaz wprowadzić i odgórnie narzucić konieczność, o której mowa jest w ostatnim zdaniu przytaczanej wypowiedzi. Nie widzę żadnej drogi, która prowadzi od mojej definicji artyficjalizmu do powyższego przekonania. Uczonym, gdy prowadzą swoje badania, nie należy niczego ani nakazywać, ani zakazywać, bo nauka jest przedsięwzięciem anarchistycznym.

Tego typu nakazy czy zakazy pojawiają się w następstwie dobrowolnej akceptacji przez samych uczonych takiej, a nie innej metafizyki i ulegają zmianom wraz z wymianą tej ostatniej na inną. Naturalistycznych wyjaśnień będą poszukiwali wyłącznie ci uczeni, którzy uznają, że w przyrodzie działa jedynie przypadek i konieczność. Zaś ci, którzy przyjmą, że obok przypadku i konieczności w przyrodzie działają również inteligentne przyczyny, w niektórych przypadkach odrzucali będą wyjaśnienia naturalistyczne.

W opinii Sagana popełniłem poważny błąd:

Kilian [...] wyraźnie przypisał terminowi ,artyficjalizm” prawidłowe znaczenie jako EUO nauki, choć zaprzepaścił to, mieszając je z EUO teorii inteligentnego projektu. ${ }^{13}$

Raz jeszcze powtórzę to, co już wyżej powiedziałem, EUO teorii inteligentnego projektu jest artyficjalizm. Ten ostatni, dodam w tym miejscu, jest również EUO archeologii, kryptologii i programu SETI. Artyficjalizm jest zatem funkcjonującym EUO dla kilku dyscyplin naukowych. Zaś to, o czym wspomniał wcześniej Sagan, że w grę wchodzą tu, jak się w kręgach naturalistycznych powszechnie przyjmuje, wyłącznie „przyczyny inteligentne (różne od ludzi, bo o takie przyczyny inteligentne toczy się spór" ${ }^{14}$ ), nie ma większego znaczenia, bo jest przekonaniem błędnym.

SETI, jak sama nazwa wskazuje, zajmuje się poszukiwaniami pozaziemskiej inteligencji. Przekonanie, że wszystkie artefakty ujawnione przez archeologię mają ziemski rodowód, jest wyłącznie pobożnym życzeniem, bo nikt nie prowadził badań zmierzających do wykrycia natury projektanta w każdym ze wspomnianych artefaktów. To, czy można na podstawie oznak inteligencji wnioskować o naturze projektanta, jest już zupełnie innym problemem (o takim wnio-

\footnotetext{
${ }^{13}$ SAGAN, „Jaki «artyficjalizm»...”, s. 232.

${ }^{14}$ SAGAN, ,Jaki «artyficjalizm»...”, s. 232.
} 
skowaniu, jak powszechnie wiadomo, w chwili obecnej, negatywnie wypowiadają się teoretycy projektu).

Sagan jest przekonany, że da się oddzielić twarde jądra od EUO:

To, co Kilian chce uznać za twarde jądra epistemicznych układów odniesienia nauki, to są w istocie tezy, które mogą, ale nie muszą być dołączane do poszczególnych EUO. EUO to proste założenia mówiące, do jakich rodzajów przyczyn wolno lub należy odwoływać się w wyjaśnieniach naukowych, zaś twarde jądra można przypisywać co najwyżej poglądom stanowiącym uszczegółowienia danych EUO. ${ }^{15}$

Moim zdaniem zabiegu takiego przeprowadzić się nie da.

Zgadzając się z tezą, w myśl której „EUO to proste założenia mówiące, do jakich rodzajów przyczyn można lub należy odwoływać się w wyjaśnieniach naukowych”, ${ }^{16}$ nie zgadzam się z tezą, że twarde jądra to „tezy, które mogą, ale nie muszą być dołączane do poszczególnych EUO". ${ }^{17}$ Założenia, o których tu mowa, są decyzjami metodologicznymi mającymi sens wyłacznie wtedy, gdy przyjmie się określone założenia dotyczące natury świata. Oto kilka powszechnie znanych przykładów potwierdzających tę tezę.

Nie należy poszukiwać nieregularności (kontrprzypadków) w świecie, którego struktura manifestuje się $\mathrm{w}$ harmonijnym zestrojeniu materii i formy lub dostępna jest $\mathrm{w}$ intuicyjnym wglądzie pozwalającym dostrzec kształtujące widzialny świat idee. A jeśli już takie nieregularności zostaną odkryte, to należy je sprowadzać do znanych regularności. (Ten sposób myślenia skutecznie uniemożliwiał wprowadzenie hipotezy eliptycznego ruchu planet.)

Jeśli świat jest konglomeratem regularności, to indukcja jest podstawowym narzędziem badania owej regularności, gdyż w badaniach świata na ogół natykali się będziemy na fakty podpadające pod ogólne zależności. Nie należy zatem zwracać uwagi na żadne kontrświadectwa aż do momentu, w którym odkryte zostaną nowe fakty, które albo indukcyjnie uzyskane prawa uściślą, albo te prawa podważą. (Ten sposób myślenia ukształtował tak zwany „klasyczny empi-

\footnotetext{
${ }^{15}$ SAGAN, „Jaki «artyficjalizm»...”, s. 236.

${ }^{16}$ SAGAN, „Jaki «artyficjalizm»...”, s. 236.

${ }^{17}$ SAGAN, ,Jaki «artyficjalizm»...”, s. 236.
} 
ryzm”, zgodnie z którym wszelka wartościowa wiedza jest efektem podążania za faktami i indukcją. ${ }^{18}$ )

Przyjmując, że świat jest zbiorem przedmiotów i ich własności, szukali będziemy praw opisujących i porządkujących zbiory przedmiotów. Zaś przyjmując, że świat jest zbiorem procesów albo zdarzeń, szukali będziemy praw odpowiednio opisujących i porządkujących zbiory procesów albo zdarzeń.

Wreszcie uniwersalnych praw, rządzących całym światem, poszukiwał będzie tylko ten, kto przyjmie, że świat jest matematycznie uporządkowaną całością, którą da się ująć za pomocą prostych teorii. Zaś ten, kto przyjmie, że świat przypomina raczej ocean anomalii niż dobrze uporządkowaną strukturę, występował będzie przeciwko wszelkim tendencjom unifikacyjnym.

Krótko mówiąc (i parafrazując Kazimierza Jodkowskiego), zanim zaczniemy szukać, musimy wiedzieć czego i gdzie mamy szukać. A zatem bez akceptacji określonych tez tworzących określone twarde jądra nigdy niczego nie odkryjemy.

Jak się zdaje, Sagan ma inną wizję nauki, w której możliwe jest odrywanie decyzji metodologicznych od uzasadniających je metafizyk. Wspominałem już, że prowadzi to $\mathrm{w}$ stronę bardzo trudnej do utrzymania wizji rozwoju nauki. Świadczy o tym na przykład taka wypowiedź Sagana:

Jodkowski i Kilian charakteryzują go [to jest artyficjalizm] w sposób problematyczny, silnie związany z teorią inteligentnego projektu. ${ }^{19}$

Jeśli problematyczność tej charakterystyki polegać ma między innymi (inny problematyczny składnik wskażę niebawem) na wiązaniu artyficjalizmu z ID, to pozwolę sobie tu przypomnieć banalną prawdę, że osią sporu o charakter dopuszczalnych w nauce wyjaśnień są właśnie nauki o życiu. Gdzie indziej tych

\footnotetext{
${ }^{18}$ Por. np. Paul K. Feyerabend, „Problems of Empiricism”, w: Robert G. Colodny (ed.), Beyond the Edge of Certainty: Essays in Contemporary Science and Philosophy, Prentice-Hall, Engelwood Cliffs, New Jersey 1965, s. 154 [145-260]; Alan E. Musgrave, „Wpływ Einsteina na filozofię", przeł. Kazimierz Jodkowski, w: Kazimierz JоDкоwSкI (red.), Na czym polega racjonalność nauki?, Realizm. Racjonalność. Relatywizm, t. 7, Wydawnictwo UMCS, Lublin 1991, s. 83 [79-105].

${ }^{19}$ SAGAN, „Jaki «artyficjalizm»...”, s. 236.
} 
sporów nie prowadzi się, przymykając oko na obecne na przykład w archeologii czy programie SETI wyjaśnienia artyficjalistyczne.

Sagan, przedstawiając bronioną przez siebie wizję nauki, twierdzi też, że

Sami jego [artyficjalizmu] główni zwolennicy, to jest teoretycy projektu, mają inną wizję natury nauki jako całości [niż ta, którą opisują Jodkowski i Kilian]. [...] Nazywając taką wizję nauki ,artyficjalizmem”, należy więc zdefiniować go po prostu jako założenie dopuszczające odwołania do różnych rodzajów przyczyn w wyjaśnieniach naukowych. ${ }^{20}$

Nazwa „artyficjalizm” wzięła się właśnie od dopuszczania w nauce przyczyn sztucznych. ${ }^{21}$ I tego właśnie, powtórzę po raz kolejny, dotyczy cały spór w obrębie nauk o pochodzeniu życia.

Jeśli Sagan uważa, że jest inaczej, to - w miejsce brania w cudzysłów nazwy ,artyficjalizm” w tytule swojego tekstu, przez co sugeruje, iż w analizowanym przez niego EUO, de facto o żaden artyficjalizm nie chodzi - może powinien zaproponować jakąś nazwę, podkreślającą założenie, które dopuszcza odwoływanie się do różnych rodzajów przyczyn w wyjaśnieniach naukowych. (Jednak sam zaznaczył wcześniej, że „wyróżnić można trzy epistemiczne układy odniesienia, czyli trzy odmienne ujęcia tego, czym jest nauka w najogólniejszym sensie tego słowa: naturalizm metodologiczny, nadnaturalizm i artyficjalizm”. ${ }^{22}$ ) Wspomnę, że taka nazwa (,neutralizm”) już istnieje, o czym Sagan doskonale wie. ${ }^{23}$

\footnotetext{
${ }^{20}$ SAGAN, „Jaki «artyficjalizm»...”, s. 236.

${ }^{21}$ Przez naturalizm Johnson i Dembski rozumieją więc ograniczanie się w nauce jedynie do przyczyn naturalnych, bezosobowych i nieinteligentnych, przeciwstawianych przyczynom inteligentnym i celowym, a niekoniecznie - nadprzyrodzonym. [...] jest to [...] rozumienie antynaturalizmu, [...] [które] przeciwstawia [...] przyczyny naturalne przyczynom sztucznym, celowym i inteligentnym.

Kazimierz Jodkowski, „Antynaturalizm teorii inteligentnego projektu”, Roczniki Filozoficzne 2006, t. 54, nr 2, s. 73 [63-76], https://tiny.p1/qzq86 (05.04.2019).

${ }^{22}$ SAGAN, ,Jaki «artyficjalizm»...”, s. 225.

${ }^{23}$ Przywołuje ją w swoim tekście: por. SAGAN, „Jaki «artyficjalizm»...”, s. 243.
} 
Sagan jest też przekonany, że zwolennicy ID są zwolennikami jakiegoś innego niż artyficjalizm (w sensie nadanym tej nazwie przez Jodkowskiego) EUO. Oto dwa cytaty, którymi Sagan wspiera swoje przekonanie, że „teoretycy projektu, mają inną [niż tylko rozszerzenie wyjaśnień naukowych o przyczyny sztuczne] wizję natury nauki jako całości”. ${ }^{24}$

\section{Cytat pierwszy:}

Naukę ,głównego nurtu” postrzegam jako podzbiór tego, co nazywam wolną nauką. Wolna nauka bierze pod uwagę każda odpowiedź sugerowana przez dane, natomiast nauka głównego nurtu ogranicza się do odpowiedzi wyrażonych $w$ kategoriach przyczyn nieinteligentnych lub odpowiedzi niewskazujących na coś wykraczajacego poza przyrodę. Nie ma zatem niczego, co nauka głównego nurtu mogłaby zrobić, a czego nie mogłaby dokonać nauka dysponująca większą wolnością, za jaką uważam teorię inteligentnego projektu. Innymi słowy, ludzie pracujący nad teorią inteligentnego projektu mogą dopuścić, że być może nic w przyrodzie nie wskazuje na to, że wpłynął na nią lub zainicjował ją jakiś czynnik inteligentny. A może jednak coś na to wskazuje. Sprawdźmy i przekonajmy się. Możemy dojść do wniosku, że w przyrodzie nie ma żadnych śladów inteligentnej aktywności. ${ }^{25}$

Jeśli dwa pierwsze zdania z wypowiedzi Behe'ego brać dosłownie, to każdej odpowiedzi sugerowanej przez dane przeciwstawiane są odpowiedzi wyrażone $\mathrm{w}$ kategoriach przyczyn nieinteligentnych. Wynikałoby z tego zatem, że każda odpowiedź sugerowana przez dane to nie tylko odpowiedź za pomocą przyczyn inteligentnych. Dwa ostatnie zdania podważają jednak takie rozumowanie, gdyż Behe wyraźnie mówi tu o przyczynach sztucznych (,jakiś czynnik inteligentny").

Cytat drugi:

Aby można było uznać, że w badaniach pochodzenia życia poszukuje się prawdy, nie należy pytać „Który scenariusz materialistyczny jest najbardziej adekwatny?”, lecz „Co naprawdę byto przyczyna powstania życia na Ziemi?" [...] Ocenianie teorii naukowych z natury polega na ich porównywaniu. Nie można twierdzić ani że teorie zy-

\footnotetext{
${ }^{24}$ SAGAN, ,Jaki «artyficjalizm»...”, s. 236.

${ }^{25}$ Wypowiedź Michaela J. Behe'ego w: Christopher CARLISLE, M.Div. and W. Thomas SMith, Jr., The Complete Idiot's Guide to Understanding Intelligent Design, Alpha, New York 2006, s. 268, przytaczana za tekstem SAGANA, „Jaki «artyficjalizm»...”, s. 236-237 [wyróżnienia dodane].
} 
skujące akceptację w sztucznie ograniczonym zbiorze rywalizujących hipotez są „,najlepsze”, ani że są „najprawdopodobniej prawdziwe”. Takie teorie mogą co najwyżej być ,najlepsze lub najprawdopodobniej prawdziwe w sztucznie ograniczonym zbiorze możliwości”. Z punktu widzenia każdej w petni racjonalnej biologii historycznej, to jest takiej, która poszukuje prawdy przy zatożeniu, że „,wszystkie chwyty sq dozwolone", otwartość na hipoteze projektu wydaje się konieczna. Biologia historyczna propagująca poglad, aby iść tropem świadectw, dokądkolwiek prowadza, nie będzie odgórnie wykluczać hipotez z powodu ich potencjalnych implikacji metafizycznych. ${ }^{26}$

Jeżeli w powyższej wypowiedzi Stephena Meyera ${ }^{27}$ Sagan pod etykietą ,iść tropem świadectw, dokądkolwiek prowadzą" widzi coś innego niż wyłącznie dopuszczanie wyjaśnień artyficjalistycznych, to muszę przyznać ze smutkiem, że ja niczego takiego dopatrzeć się tu nie mogę, bo nieustannie dostrzegam tu jedynie Meyerowską „otwartość na hipotezę projektu”.

Oczywiście istnieją dużo bardziej radykalne wypowiedzi na temat swobody w podążaniu za świadectwami, które przytaczam w jednym ze swoich artykułów, ${ }^{28}$ (Sagan również zwraca uwagę na takie wypowiedzi ${ }^{29}$ ) nie są to jednak wypowiedzi czołowych teoretyków projektu, tylko komentatorów, którzy, na co również wskazuję w swoim tekście, nie do końca wiedzą, co mówią. Behe i Meyer są znacznie bardziej powściągliwi w swoich wypowiedziach, swobody $\mathrm{w}$ podążaniu za świadectwami upatrując wyłacznie w dopuszczaniu wyjaśnień artyficjalistycznych.

Artyficjalizm, jak widzi go Sagan, to nic innego niż propozycja dopuszczania w nauce najlepszych wyjaśnień:

O tym, jakie wyjaśnienia zostaną uznane za najlepsze - naturalistyczne, nadnaturalistyczne czy powołujące się na przyczyny inteligentne - mają decydować dane empi-

\footnotetext{
${ }^{26}$ Stephen C. Meyer, Signature in the Cell: DNA and the Evidence for Intelligent Design, HarperOne, New York 2009, s. 437-438. Wypowiedź przytaczana za tekstem SAGANA, „Jaki «artyficjalizm»...", s. 237 [wyróżnienia dodane].

${ }^{27}$ To, że Meyer ze swojego ulubionego stanowiska w sporze o status teorii naukowych, czyli z naukowego realizmu, uczynił stanowisko powszechnie obowiązujące, pomijam tu milczeniem.

${ }^{28}$ Por. Krzysztof J. KiLIAN, „Argumenty przeciwko naturalizmowi jako epistemicznemu układowi odniesienia”, Filozoficzne Aspekty Genezy 2018, t. 15, s. 107-111 [71-137], https://tiny.pl/tg j9g (19.05.2019).

${ }^{29}$ Por. SAGAN, „Jaki «artyficjalizm»...”, s. 243-244.
} 
ryczne (w praktyce utrudniane będzie to jednak przez uteoretyzowanie obserwacji), a nie restrykcyjne założenia co do natury nauki. ${ }^{30}$

Jednakże pojawia się tu problem, czym różni się uteoretyzowanie obserwacji od akceptacji restrykcyjnych założeń dotyczących natury nauki, czyli konkretnych EUO, u podstaw których tkwią twarde jądra, czyli metafizyczne tezy mówiące o tym, co istnieje? Wraz z tym problemem pojawia się pytanie, o jakim rodzaju uteoretyzowania obserwacji mówi Sagan?

Uteoretyzowanie obserwacji, na co on sam również zwracał uwagę w swoich publikacjach, nie jest nazwą, która ma jedno znaczenie. W myśl podejścia, które akceptuje i on, mówi się, że uteoretyzowanie obserwacji może być rozumiane na trzy sposoby. Ja zaś twierdzę, że tylko przyjęcie jednej z tez o łagodnym albo umiarkowanym uteoretyzowaniu obserwacji pozwala odróżnić uteoretyzowanie obserwacji od przyjmowanego EUO.

Stanowisko najłagodniejsze utrzymuje, że istnieją teoretycznie neutralne obserwacje. Uteoretyzowanie rozumiane jest tu jako zogniskowanie uwagi - różne teorie mogą akcentować odmienne obserwacje, każda teoria może wybierać istotne dla niej obserwacje i pomijać nieistotne. Stanowisko umiarkowane sprowadza się do przekonania, że w każdej obserwacji da się wyróżnić dwa elementy: teoretyczny i obserwacyjny. Podczas przechodzenia od teorii do teorii dochodzi do zmiany interpretacji faktów, a nie samych danych czy faktów. ${ }^{31}$

W myśl obydwu podejść da się, z większym lub mniejszym trudem, oddzielić dane empiryczne od interpretacji tych danych, zaś takie dane, nawiązując do ujęcia Sagana („o tym, jakie wyjaśnienia zostaną uznane za najlepsze - naturalistyczne, nadnaturalistyczne czy powołujące się na przyczyny inteligentne mają decydować dane empiryczne" ${ }^{32}$ ), pozwalają na wybór najlepszego wyjaśnienia. Obydwa podejścia uznawane są za przestarzałe, ponieważ powszechnie przyjmuje się tezę, w myśl której oddzielanie pojęć teoretycznych od pojęć ob-

\footnotetext{
${ }^{30}$ SAGAN, ,Jaki «artyficjalizm»...”, s. 239.

${ }^{31}$ Por. np. Kazimierz JodкоwsкI, Teza o niewspólmierności w ujęciu Thomasa S. Kuhna i Paula K. Feyerabenda, Realizm. Racjonalność. Relatywizm, t. 1, Wydawnictwo UMCS, Lublin 1984, s. 16-17.

${ }^{32}$ SAGAN, „Jaki «artyficjalizm»...”, s. 240.
} 
serwacyjnych, a co za tym idzie języka teoretycznego od języka obserwacyjnego, jest niemożliwe.

Nawiasem mówiąc, oddzielać takie pojęcia można jedynie w specyficzny sposób, wyłącznie na gruncie pragmatycznej teorii obserwacji. Ta ostatnia mówi, że podział języka nauki na obserwacyjny i teoretyczny ma charakter umowny, zależny jest zarówno od stopnia wytrenowania uczonego, jak i posiadanej przez niego wiedzy. Nieco inaczej to wyrażając, pojęcia powinny być uważane za obserwacyjne lub teoretyczne w zależności od tego, kto dokonuje obserwacji. ${ }^{33}$

Stanowisko skrajne kładzie nacisk na to, że obserwacje są całkowicie zależne od teorii, w następstwie czego zmiana teorii powoduje zmianę widzenia świata. ${ }^{34}$ Zgodnie $\mathrm{z}$ tym ostatnim podejściem nie ma możliwości weryfikacji benda:

${ }^{33}$ Można to zobrazować dwoma znakomitymi przykładami. Pierwszy pochodzi od Feyera-

Astronom, dzięki interferometrycznym obserwacjom, fotografiom spektralnym itp., może być dobrze obznajomiony z jakąś gwiazdą, która jest ledwo widoczna gołym okiem. Pewnego wieczoru, patrząc w niebo, widzi znaczący wzrost jasności gwiazdy. „Supernowa”! (Bezpośrednio zaobserwowana!) krzyczy, biegnąc do spektroskopu i interferometru. Wydatnie ukazały się linie helu: hel jest wyrzucany przez atmosferę. Linie te mają cienkie, jasne jądro: zewnętrzna powierzchnia gwiazdy otoczona jest przez warstwę gorących gazów, po której następuje warstwa gęstsza, bardziej chłodna. Przesunięcie w interferometrze pokazuje średnicę pięćset razy większą itp. Kto mógłby chcieć powiedzieć, że nie jest to bezpośrednia obserwacja przeprowadzona przez wprawnego astronoma?

Paul K. Feyerabend, „The Problem of the Existence of Theoretical Entities”, w: Paul K. Feyerabend, Philosophical Papers. Vol. 3. Knowledge, Science and Relativism, ed. John Preston, Cambridge University Press, Cambridge - New York - Melbourne - Madrid - Cape Town — Singapore - Sao Paulo 2008, s. 20-21 [16-49].

Zaś drugi przykład pochodzi od Jodkowskiego:

zgodnie z [...] [pragmatyczną] teorią [obserwacji] nie jest tak, że odpowiednio wytrenowany biolog widzi tylko specyficznie zorganizowane grupy poruszających się kolorowych plamek w mikroskopie i dopiero na tej podstawie wnioskuje, że są to pantofelki. On po prostu obserwuje pantofelki (choć może się mylić).

Kazimierz Jodkowski, „Filozofia nauki Paula K. Feyerabenda. Stadium umiarkowane”, Studia Filozoficzne 1979, nr 11 (168), s. 65 [59-75].

${ }^{34}$ Por. np. JodKowski, Teza o niewspólmierności..., s. 16-17. 
faktów niezależnie od teorii, gdyż nie istnieje neutralny język obserwacyjny, za pomocą którego można takiego sprawdzenia dokonać. ${ }^{35}$ Powodem odwoływania wyników obserwacyjnych może być nie tylko dostrzeżenie, że popełniono błąd, czy niedopatrzenie w samym procesie obserwowania jakiegoś zjawiska. Obserwacje odwołać można niezależnie od tego procesu, pod wpływem zmian, jakie dokonały się w teoretycznej części wiedzy. ${ }^{36}$

Powiedzieć zatem można, że mocne uteoretyzowanie obserwacji polega na tym, że przyjmowane (świadomie lub nieświadomie) założenia dotyczące struktury świata dopuszczają takie, a nie inne jego postrzeganie. Nie poznaje się świata jako takiego, tylko świat wedle określonej teorii (języka):

\footnotetext{
${ }^{35}$ Por. np. Paul K. Feyerabend, „Reply to Criticism: Comments on Smart, Sellars and Putnam”, w: Paul K. Feyerabend, Philosophical Papers. Vol. 1. Realism, Rationalism \& Scientific Method, Cambridge University Press, Cambridge - New York - Portchester - Melbourne Sydney 1981, s. 124-127 [104-131]; Michael DevitT, „Against Incommensurability”, Australasian Journal of Philosophy 1979, vol. 57, no. 1, s. 32 [29-50].

${ }^{36}$ To ostatnie stwierdzenie bardzo dobrze obrazuje następująca wypowiedź Feyerabenda:

Czary stanowią tu [...] bardzo dobry przykład. Liczni naoczni świadkowie twierdzili, że widzieli diabła, lub że doznali demonicznego wpływu. Nie ma też żadnego powodu, by przypuszczać, że kłamali. Nie ma też powodu, aby przyjąć, że byli niedbałymi obserwatorami, ponieważ zjawiska leżące u podstaw przekonania o demonicznym wpływie są tak oczywiste, że błąd jest prawie niemożliwy (opętanie, rozdwojenie czy utrata osobowości, słyszenie głosów, etc.). Zjawiska te są dziś dobrze znane. W schemacie pojęciowym powszechnie przyjętym w XV i XVI wieku jedynym sposobem ich opisania, czy przynajmniej środkiem, który zdawał się wyrażać je najtrafniej, było odwołanie się do demonicznych wpływów. Znaczna czesść tego schematu pojęciowego została zmieniona z powodów filozoficznych [...]. Materializm Kartezjusza odegrał decydującą rolę w zdyskredytowaniu wierzeń w zlokalizowane przestrzennie duchy. Język demonicznych wpływów nie wchodzi w skład nowego schematu pojęciowego, który stworzono w ten sposób. Z tych względów konieczne było przeformułowanie i reinterpretacja nawet najbardziej potocznych stwierdzeń „obserwacyjnych”.
}

Paul K. Feyerabend, „Jak być dobrym empirystą? Wezwanie do tolerancji w kwestiach epistemologicznych", w: Paul K. Feyerabend, Jak być dobrym empirystą, przeł. Krystyna Zamiara, Państwowe Wydawnictwo Naukowe, Warszawa 1979, s. $49-50$ [23-61].

Warto tu też nadmienić, że idea pełnego uteoretyzowania obserwacji nie prowadzi do idei pełnej plastyczności obserwacji. Uteoretyzowanie faktów nie jest tożsame z prawdziwościowym uzgodnieniem ich z teorią. Uteoretyzowane przez daną teorię fakty mogą być z teorią niezgodne (por. np. Paul K. Feyerabend, Przeciw metodzie, przeł. Stefan Wiertlewski, Wydawnictwo SIEDMIORÓG, Wrocław 1996, s. 201). 
dlaczego nie widzę ID w organizmach biologicznych [?] [...] Patrzę i patrzę, i nie znajduję ID, a to z kolei wzmacnia moje skłonności do ateizmu. Mimo to kreacjoniści ID potrafią zobaczyć ID tam, gdzie ja go nie widzę. ${ }^{37}$

$\mathrm{Z}$ nieco innej strony na to patrząc, mocne uteoretyzowanie obserwacji jest połączeniem kompleksów wrażeń zmysłowych z wcześniej nabytymi schematami porządkowania świata i pojęciami:

uderzające anatomiczne podobieństwa, np. w strukturze szkieletu, między kręgowcami ewolucjoniści interpretują jako wskazówki świadczące o wspólnym przodku. [...] Kreacjoniści z drugiej strony widzą te same dane jako świadectwo o wspólnym projektancie. ${ }^{38}$

Sagan, rozszerzając swoją argumentację na rzecz tezy, że wizja nauki, jakiej bronią teoretycy projektu, to coś więcej niż dopuszczanie wyjaśnień artyficjalistycznych, przekonuje, że

nawet $\mathrm{w}$ ramach teorii inteligentnego projektu dopuszczalne są odwołania do przyczyn nadnaturalnych. ${ }^{39}$

Na końcu tego zdania dał przypis odsyłający między innymi do trzech źródłowych publikacji. ${ }^{40}$ Szkoda, że nie przytoczył żadnej konkretnej wypowiedzi, która wspierałaby bronioną przez niego tezę, gdyż teksty te, przynajmniej w mojej opinii, nie mówią w jakiś jednoznaczny sposób o dopuszczalności wy-

${ }^{37}$ William B. Provine, „Projekt? Tak! Ale czy inteligentny?”, przeł. Sławomir Piechaczek, Filozoficzne Aspekty Genezy 2005/2006, t. 2/3, s. 224 [217-237], https://tiny.pl/xh8rs (08.04. 2019).

${ }^{38}$ Dean H. Kenyon, „Kreacjonistyczne ujęcie pochodzenia życia”, przeł. Kazimierz Jodkowski, w: Kazimierz Joркошsкі, Metodologiczne aspekty kontrowersji ewolucjonizm kreacjonizm, Realizm. Racjonalność. Relatywizm, t. 35, Wydawnictwo UMCS, Lublin 1998, s. 494 [482-495].

${ }^{39}$ SAGAN, ,Jaki «artyficjalizm»...”, s. 238.

${ }^{40}$ William A. Dembsкi, The End of Christianity: Finding a Good God in an Evil World, B\&H Publishing Group, Nashville, Tennessee 2009, s. 91-92; William A. DemBski, „The Incompleteness of Scientific Naturalism”, w: Jon Buell and Virginia Hearn (eds.), Darwinism: Science or Philosophy? Proceedings of a Symposium Entitled Darwinism: Scientific Inference or Philosophical Preference?, Foundation for Thought and Ethics, Dallas, Texas 1993, http://tiny. pl/xh8lp (08.04.2019); Bradley MonTon, Seeking God in Science: An Atheist Defends Intelligent Design, Broadview Press, Canada 2009, s. 51-52. 
jaśnień nadnaturalistycznych. Przykładowo w jednym z tych tekstów Dembski tak podsumowuje własne rozważania:

Moim celem było pokazanie, że naukowy naturalizm jest niekompletny. [...] można [zatem] zrezygnować z naturalizmu i wprowadzić zupełnie inną [...] metafizyczną hipotezę - Boga. Te dwa wybory nie wyczerpują wszystkich możliwości, ale są zdecydowanie najpowszechniejsze. ${ }^{41}$

I kończy następującą konkluzją:

Drzwi pozostają zatem szeroko otwarte na, dające się obronić środkami naukowymi, wyjaśnienie za pomocą inteligentnego projektu. ${ }^{42}$

Trudno to uznać za wyraźną deklarację na rzecz dopuszczania w obrębie ID wyjaśnień nadnaturalistycznych („te dwa wybory nie wyczerpują...”). Wspomnę też w tym miejscu o dwóch powszechnie znanych faktach, że: (a) ID programowo powstrzymuje się od rozstrzygania natury projektanta, a uznanie, iż konkretne wyjaśnienie ma zarazem charakter nadnaturalistyczny i artyficjalistyczny, jest zajęciem stanowiska w kwestii, której ID rozstrzygać nie chce; (b) ID da się uzgodnić $\mathrm{z}$ naturalizmem i nadnaturalizmem.

Przekonanie, którego broni Sagan, wspomagane jest przez niego również następującym rozumowaniem:

I chociaż teoretycy projektu utrzymują, że wykrywane w przyrodzie oznaki projektu nie muszą umożliwiać identyfikacji projektanta, dzięki czemu nie ma między innymi konieczności powoływania się na istotę nadnaturalną, to w określonych okolicznościach mogą na to pozwalać, wskazując nawet na nadnaturalnego projektanta. Gdyby na przykład w genomach organizmów żywych odkryto jakieś zakodowane wiadomości, jak ,stworzone przez Jahwe”, albo - jeszcze lepiej — gdyby zakodowano tam całą treść Biblii, to naukowcy mogliby uznać, że jest to silny argument (choć nie dowód) za tym, że twórcą tych informacji jest konkretna istota nadnaturalna. ${ }^{43}$

Tego typu argumenty są obosieczną bronią. Nic bowiem nie stoi na przeszkodzie w przyjęciu równosilnego argumentu (choć nie dowodu), w myśl któ-

\footnotetext{
${ }^{41}$ DemBSKI, „The Incompleteness...”.

${ }^{42}$ Dembski, „The Incompleteness...”.

${ }^{43}$ SAGAN, ,Jaki «artyficjalizm»...”, s. 238.
} 
rego ateistycznie usposobieni naukowcy mogliby też uznać, że jakaś naturalnie powstała istota (i zarazem przedstawiciel pozaziemskiej cywilizacji) była zdolna wykonać pewne fragmenty naszych organów i rozpowszechnić życie na Ziemi. Istota ta, chcąc ukryć swoją obecność - czy to ze względu na wrodzoną skromność, czy też ze względu na niechęć do ewentualnego wyjaśniania nam wielu spraw, o które z chęcią byśmy ją zapytali, a których jej się po prostu wyjaśniać nie chce - wymyśliła sobie, że najlepiej to zrobi, dając nam tekst Biblii, który przekona nas, że ona to nie ona. A gdyby jeszcze dodatkowo Pismo Święte zakodowała $\mathrm{w}$ naszych genomach, to już z całą pewnością nie przyszłoby nam na myśl, by wnioskować o jej naturalistycznym rodowodzie.

Sagan, broniąc swojego przekonania, zgodnie z którym teoretycy projektu mają znacznie szerszą od czysto artyficjalistycznej wizję nauki, oczywiście zauważył, że

teoretycy projektu piszą niekiedy o nienaukowym charakterze wyjaśnień nadnaturalistycznych: „wyjaśnienia nadnaturalistyczne, odwołujące się do cudów, nie są naukowe. Wyjaśnienia, które odwołują się do inteligentnej przyczyny, nie wymagają żadnych cudów, ale nie można ich zredukować do mechanizmów materialistycznych". ${ }^{44}$

Niezgodność stanowiska teoretyków projektu z bronionym przez siebie przekonaniem wyjaśnia następująco:

Wyjaśnienie nadnaturalistyczne nie musi jednak odwoływać się do cudów. Jeśli jakieś cechy zjawisk przyrodniczych, takie jak wspomniane w tekście głównym informacje zakodowane w genomach, wskazywałyby na nadnaturalnego projektanta, odwołanie się do niego miałoby charakter wyjaśnienia nadnaturalistycznego. ${ }^{45}$

Niestety informacje zakodowane w genomach wskazywały będą jedynie na inteligentnego projektanta, gdyż, jak wskazałem wyżej, rozstrzyganie natury projektanta jest uzależnione od ontologicznego zaangażowania tego, kto takiego rozstrzygnięcia chciał będzie dokonać. A co za tym idzie, odwołanie się do pro-

${ }^{44}$ William A. Dembski and Jonathan Wells, The Design of Life: Discovering Signs of Intelligence in Biological Systems, Foundation for Thought and Ethics, Dallas 2008, s. 13-14. Sagan (w: SAGAN „Jaki «artyficjalizm»...”, s. 238 przyp. 28) odnotował też, iż „na tę wypowiedź zwraca uwagę również Kilian".

${ }^{45}$ SAGAN, „Jaki «artyficjalizm»...”, s. 238-239 przyp. 28. 
jektanta będzie miało, wedle upodobań ontologicznych, charakter wyjaśnienia albo artyficjalistycznego, albo nadnaturalistycznego.

Zdaniem Sagana między artyficjalizmem i nadnaturalizmem istnieje znacznie bardziej istotna różnica od tej, na którą wskazuję ja:

przedstawiona przez Kiliana charakterystyka nadnaturalizmu jako nakazu dopuszczania w nauce odwołań do przyczyn nadnaturalnych [...] jest nieadekwatna. Rzeczywista różnica między artyficjalizmem a nadnaturalizmem polega na tym, że to ten pierwszy tylko dopuszcza wyjaśnienia nadnaturalistyczne, a drugi — nakazuje korzystanie $\mathrm{z}$ takich wyjaśnień $\mathrm{w}$ odgórnie określonych przypadkach, na przykład przy powstaniu Wszechświata, życia czy różnych jego form. ${ }^{46}$

Nie ulega najmniejszej wątpliwości fakt, że Sagan dużo lepiej ode mnie zna teksty teoretyków projektu. Nie powinno to jednak przesłaniać innego faktu, że lansowane przez niego przekonanie, zgodnie z którym artyficjalizm dopuszcza wyjaśnienia nadnaturalistyczne, nie znalazło ugruntowania w przywoływanych przez niego tekstach teoretyków ID. Zaś jego argument o dopuszczaniu wyjaśnień nadnaturalistycznych z oznak projektu jest jedynie argumentem o dopuszczaniu wyjaśnień o istnieniu inteligentnego projektanta z oznak projektu.

Niestety na pytanie o to, czym różni się nakaz dopuszczania wyjaśnień nadnaturalistycznych od nakazu korzystania z takich wyjaśnień, nie jestem w stanie odpowiedzieć. Moim zdaniem różnica między nimi polega na użyciu innych słów. Równie trudno byłoby powiedzieć, czym różni się nakaz dopuszczania wyjaśnień artyficjalistycznych od nakazu korzystania z takich wyjaśnień w odgórnie określonych przypadkach (o których mówi warunek Jodkowskiego).

To, co Kilian chce uznać za twarde jądra epistemicznych układów odniesienia nauki, to w są istocie tezy, które mogą, ale nie muszą być dołączane do poszczególnych EUO. ${ }^{47}$

Powodem, dla którego Kilian przypisuje epistemicznym układom odniesienia twarde jądra, jest próba poparcia tezy o założeniowości nauki - w tym wypadku nauki jako całości. Teza ta ma jednak poparcie, nawet gdy poszczególne EUO nie mają twardych jąder, zwłaszcza obejmujących tak mocne założenia ontologiczne, o jakich pisze Kilian. Określenie z góry, które z logicznie możliwych rodzajów przyczyn należy lub

\footnotetext{
${ }^{46}$ SAGAN, „Jaki «artyficjalizm»...”, s. 239 przyp. 29 [wyróżnienia w oryginale].

${ }^{47}$ SAGAN, ,Jaki «artyficjalizm»...”, s. 237.
} 
można stosować w wyjaśnieniach naukowych, to przecież nic innego jak założenie metodologiczne przyjmowane, w zasadzie, na mocy arbitralnej decyzji. ${ }^{48}$

Nie rozumiem pierwszego zdania z drugiej wypowiedzi Sagana, a konkretnie następującego fragmentu: „tezy o założeniowości [...] nauki jako całości”, i dlatego nie wiem, czy jestem zwolennikiem tej tezy. Jeśli chodzi w nim o to, że istnieje jakaś całość zwana nauką, która przyjmuje takie, a nie inne założenia, to nie jestem zwolennikiem tej tezy. Zaś jeśli chodzi w nim o to, że powszechnie w nauce, pojmowanej jako szereg rozmaitych przedsięwzięć, przyjmuje się różne założenia metafizyczne, to jestem zwolennikiem tej tezy. Teza o założeniowości, której jestem zwolennikiem, jest zatem tezą o nieredukowalnej obecności metafizyki (a dokładniej różnych metafizyk) w szeregu rozmaitych przedsięwzięć zwanych nauką. Dalej będę miał na myśli to drugie rozumienie.

Drugie zdanie z omawianej wypowiedzi Sagana pozwala przypuszczać, że tezę o założeniowości nauki rozumie on w inny sposób: w przedsięwzięciach naukowych mocą arbitralnej decyzji dopuszcza się jedne przyczyny, a wyklucza drugie.

Jest to bardzo ogólne rozumienie $\mathrm{i}$, jako takie, ma dwa istotne mankamenty. Po pierwsze, ,arbitralny” nie znaczy ani „dowolny”, ani „umowny”, choć to drugie jego znaczenie zaczyna się już pojawiać w języku polskim. " "Arbitralny” to (od łac. arbiter — „rozjemca”, ,sędzia”, ,pan”, ,władca”) ,stanowczy”, „apodyktyczny”, ,narzucający komuś swoje zdanie”, ${ }^{50}$ zaś arbitralna decyzja to decyzja narzucona w sposób stanowczy. Decyzje metodologiczne są oczywiście pewnego rodzaju umowami, co nie oznacza jednak, że podejmowane są w sposób, za którym nie kryją się jakieś istotne powody.

Warto tu też nadmienić, że istnieje pogląd zwany elitaryzmem (jego zwolennikami byli na przykład Poincaré, Duhem i Lakatos), w myśl którego to elity naukowe decydują o tym, jak uprawia się naukę, co innymi słowy da się powiedzieć, że to elity naukowe podejmują decyzje dotyczące tego, jakie wyjaśnienia są w nauce dopuszczalne (elity narzucają wspólnotom uczonych określonego ro-

\footnotetext{
${ }^{48}$ SAGAN, „Jaki «artyficjalizm»...”, s. 239.

${ }^{49}$ Por. https://tiny.pl/tt3xt (08.04.2019).

${ }^{50} \mathrm{https}: / /$ tiny.pl/tt3xt (08.04.2019).
} 
dzaju konwencje). Przykładowo Kartezjusz w liście do Marina Mersenne’a pisał tak:

Wydaje mi się, iż [Galileusz] [...] jedynie szukał przyczyn poszczególnych skutków bez uprzedniego rozważenia [...] pierwszych przyczyn [...]; a zatem budował bez fundamentów. ${ }^{51}$

Oto inny przykład (Newtona) decyzji metodologicznej:

Nie dopuszczamy więcej przyczyn rzeczy naturalnych niż te, które są zarówno prawdziwe, jak i wystarczające dla wyjaśnienia zjawisk. ${ }^{52}$

Po drugie, jeśli coś przyjmowane jest arbitralnie, to stoją za tym jakieś racje, na przykład autorytet, argument czy metafizyka. Zarzuty Kartezjusza - ignorowanie przez Galileusza nakazu wyjaśniania przez ostateczne przesłanki - są efektem przyjmowania przez tego pierwszego, wywodzącej się od Arystotelesa, metafizycznej tezy, w myśl której istnieją fundamentalia (dane intuicji intelektualnej). Są to niezawodne i niedowodliwe przesłanki — jedyny punkt wyjścia rzetelnej wiedzy:

twierdzimy, że nie wszelka wiedza jest demonstratywna, gdyż znajomość przesłanek bezpośrednich jest niezależna od dowodu, a konieczność tego jest oczywista; skoro bowiem musimy znać pierwsze przesłanki, na których opiera się dowód i skoro cofanie musi się zatrzymać na przesłankach bezpośrednich, to muszą być one niedowodliwe. ${ }^{53}$

Przesłanki te nie dają się podważyć, dzięki czemu są niekorygowalne, ostateczne i prawdziwe.

Wiedza naukowa i intuicja rozumowa są zawsze prawdziwe. ${ }^{54}$

\footnotetext{
${ }^{51}$ Cyt za: Feyerabend, Przeciw metodzie..., s. 63.

${ }^{52}$ Isaac Newton, Matematyczne zasady filozofii przyrody, przeł. Jarosław Wawrzycki, Copernicus Center Press, Kraków 2011, s. 536.

${ }^{53}$ Arystoteles, Analityki wtóre, przeł. Kazimierz Leśniak, Państwowe Wydawnictwo Naukowe, Warszawa 1973, I, 3, 72 b.

${ }^{54}$ Arystoteles, Analityki wtóre..., II, 19, 100 b.
} 
Przesłanki, o których tu mowa, można poznać, ale nie można poddać ich dalszej analizie:

nie ma zaś fałszu w odniesieniu do takich rzeczy, a jest tylko niewiedza. ${ }^{55}$

Arbitralność decyzji, z perspektywy której Kartezjusz krytykował Galileusza, ma zatem swoje źródło w określonej metafizyce.

Zaś przytoczona wyżej Newtonowska decyzja, co nietrudno zauważyć, przypomina brzytwę Ockhama. Decyzja, o której tu mowa, wyraża, rozpowszechnione w czasach Newtona, przekonanie o ekonomii dziatań Boga, która powinna odnajdywać swoje odbicie w ludzkich działaniach. ${ }^{56}$ Sam Newton uzupełnił ją komentarzem, że przyroda zadowolona jest z prostoty i nie afiszuje się ze sztucznymi przyczynami.

Wspomniane wyżej trzy racje (autorytet, argument i metafizykę) odnaleźć można w następującej wypowiedzi Johannesa Keplera, w której uzasadnia on swoją decyzję porzucenia hipotezy orbity kolistej:

mój [...] błąd polegał na tym, że tor planety uważałem za doskonałe koło, a pomyłka ta kosztowała mnie tym więcej czasu, że tak nauczano w oparciu o autorytet wszystkich filozofów, a samo w sobie było to zgodne z metafizyka. ${ }^{57}$

Nietrudno też w powyższej wypowiedzi dostrzec źródło przekonania, że jedynym właściwym torem planety jest okrąg.

Oddzielenie decyzji metodologicznych od uzasadniających je metafizyk nie jest zatem zabiegiem, który da się przeprowadzić tak ławo, jak sugeruje Sagan:

Standardy, którymi się posługujemy, i reguły przez nas zalecane mają sens jedynie w świecie posiadającym pewną strukturę. Natomiast tracą zastosowanie lub stają się nieefektywne w dziedzinie, która nie wykazuje takiej struktury. Gdy usłyszano o od-

\footnotetext{
${ }^{55}$ Arystoteles, Metafizyka, przeł. Kazimierz Leśniak, Wydawnictwo Naukowe PWN, Warszawa 2013, 1052 a.

${ }^{56}$ Por. Jerzy KIERuL, Izaak Newton. Bóg, światlo i świat, Oficyna Wydawnicza Quadrivium, Wrocław 1996, s. 188.

${ }^{57}$ Cyt. za: A. Rupert Hall, Rewolucja naukowa 1500-1800. Kształtowanie się nowożytnej postawy naukowej, przeł. Tadeusz Zembrzuski, Instytut Wydawniczy PAX, Warszawa 1966, s. 154-155 [wyróżnienia dodane].
} 
kryciach Kolumba, Magellana, Diaza, zdano sobie sprawę, że istnieją kontynenty, klimaty, rasy, których nie wymieniano w starożytnych opisach, i zaczęto domniemywać, iż mogą istnieć także nowe kontynenty wiedzy, że może istnieć jakaś „Ameryka Wiedzy”, tak samo jak istnieje nowy byt geograficzny zwany „Ameryką”. Próbowano więc ją odkryć, wyprawiając się poza granice zastanych idei. Tak oto wymóg zwiększania treści wiedzy uzyskał kluczowe znaczenie. Wyrósł on z pragnienia, aby coraz głębiej poznawać naturę, która wydała się nieskończenie bogata ilościowo i jakościowo. Wymóg ten nie ma sensu w skończonym świecie zbudowanym ze skończonego zestawu podstawowych jakości. ${ }^{58}$

Ostatnia kwestia, do której chciałbym się tu ustosunkować,

dotyczy wieloznaczności terminu „epistemiczny układ odniesienia”. Jeśli jasno się go nie zdefiniuje, może on oznaczać różne rzeczy. Okazuje się, że można odnieść go zarówno do teorii, jak i do całej nauki, a równie dobrze da się go zastosować do paradygmatów czy programów badawczych. ${ }^{59}$

W drugim zdaniu swojej wypowiedzi Sagan ma rację. Jednak to, że EUO można odnieść ( $\mathrm{z}$ różnymi ograniczeniami, na które wskazywałem ${ }^{60}$ ) do teorii, paradygmatów, programów badawczych czy też nawet do całej nauki (zapewne chodzi tu o na przykład takie rozumienie „całej nauki”: EUO współczesnej nauki jest naturalizm metodologiczny) wcale nie oznacza, że nazwa ta oznacza różne przedmioty. Za każdym razem, na co też zwracałem uwagę w swoich publikacjach, będzie ona oznaczała dwu- lub trzyelementowy szereg elementarnych założeń, mówiących, jak można uprawiać naukę i jak tego robić nie można. ${ }^{61}$

W pierwszym zdaniu z przytaczanej wypowiedzi Sagana trafnie zauważa on, że nazwa „epistemiczny układ odniesienia” nie ma statusu terminu (nazwy zarazem ostrej i wyraźnej). Warto powiedzieć, dlaczego sprawy tak się mają. Istnieją przynajmniej trzy powody. Po pierwsze, nie przebadano jeszcze dziejów

\footnotetext{
${ }^{58}$ Feyerabend, Przeciw metodzie..., s. 234.

${ }^{59}$ SAGAN, „Jaki «artyficjalizm»...”, s. 242.

${ }^{60}$ Por. Krzysztof J. Kilian, „Czym są epistemiczne układy odniesienia?”, Filozoficzne Aspekty Genezy 2017, t. 14, s. 213-218 [191-236], https://tiny.pl/g86dn (19.05.2019).

${ }^{61}$ Por. np. Kilian, „Czym są epistemiczne...”, s. 192-193; Krzysztof J. Kilian, „Geneza idei epistemicznych układów odniesienia i ich odmiany”, Filozoficzne Aspekty Genezy 2017, t. 14, s. 144 [137-190], https://tiny.pl/g2zqn (19.05.2019).
} 
nauki pod kątem ustalenia, ile takich układów da się w nauce odnaleźć. Efektem tego stanu rzeczy jest, po drugie, to, że wszystkie do tej pory zaproponowane definicje tej nazwy moga nie wyczerpywać jej zakresu. A po przecie, wszystkie zaproponowane do tej pory definicje są de facto definicjami projektującymi, gdyż nie ma jeszcze ustalonego i przyjętego sposobu posługiwania się nazwą nawet w takiej postaci, jaką nadał jej Kazimierz Jodkowski. ${ }^{62}$

Krzysztof J. Kilian

\section{Bibliografia}

Arystoteles, Analityki wtóre, przeł. Kazimierz Leśniak, Państwowe Wydawnictwo Naukowe, Warszawa 1973.

Arystoteles, Metafizyka, przeł. Kazimierz Leśniak, Wydawnictwo Naukowe PWN, Warszawa 2013.

Buell Jon and Hearn Virginia (eds.), Darwinism: Science or Philosophy? Proceedings of a Symposium Entitled Darwinism: Scientific Inference or Philosophical Preference?, Foundation for Thought and Ethics, Dallas, Texas 1993.

Carliste Christopher, M.Div. and Smith W. Thomas, Jr., The Complete Idiot's Guide to Understanding Intelligent Design, Alpha, New York 2006.

Colodny Robert G. (ed.), Beyond the Edge of Certainty: Essays in Contemporary Science and Philosophy, Prentice-Hall, Engelwood Cliffs, New Jersey 1965.

Dembsкi William A. and Wells Jonathan, The Design of Life: Discovering Signs of Intelligence in Biological Systems, Foundation for Thought and Ethics, Dallas 2008.

Dembsкi William A., The End of Christianity: Finding a Good God in an Evil World, B\&H Publishing Group, Nashville, Tennessee 2009.

Dembsкi William A., „The Incompleteness of Scientific Naturalism”, w: Buell and HearN (eds.), Darwinism: Science or Philosophy..., http://tiny.pl/xh8lp (08.04.2019).

\footnotetext{
${ }^{62}$ Przykładowo, choć przywołuje się ujęcie Kazimierza Jodkowskiego, to nazwa ta odnoszona jest do bardzo konkretnych osiągnięć naukowych (por. Radosław KaziBut, „Filozoficzna gramatyka praktyki laboratoryjnej Hasoka Changa a epistemiczny układ odniesienia Roberta Boyle'a”, w: Lidia Godek, Maciej Musią i Marek Woszczak (red.), X Polski Zjazd Filozoficzny. Księga streszczeń, Wydawnictwo Naukowe Instytutu Filozofii UAM, Poznań 2015, s. 419-420; Radosław Kazibut, „Potentia absoluta i epistemiczny układ odniesienia Roberta Boyle'a”, FiloSofija 2015, vol. 15, nr 30, s. 111-122, https://tiny.pl/gzntk [08.04.2019]).
} 
Devitr Michael, „Against Incommensurability”, Australasian Journal of Philosophy 1979, vol. 57 , no. 1 , s. 29-50.

Feyerabend Paul K., Jak być dobrym empirystą, przeł. Krystyna Zamiara, Państwowe Wydawnictwo Naukowe, Warszawa 1979.

FeYerabend Paul K., ,Jak być dobrym empirystą? Wezwanie do tolerancji w kwestiach epistemologicznych", w: FEYERABEND, Jak być dobrym empirystą ..., s. 23-61.

Feyerabend Paul K., Philosophical Papers. Vol. 1. Realism, Rationalism \& Scientific Method, Cambridge University Press, Cambridge - New York - Portchester - Melbourne - Sydney 1981.

Feyerabend Paul K., Philosophical Papers. Vol. 3. Knowledge, Science and Relativism, ed. John Preston, Cambridge University Press, Cambridge - New York - Melbourne Madrid - Cape Town - Singapore - Sao Paulo 2008.

Feyerabend Paul K., „Problems of Empiricism”, w: Colodny (ed.), Beyond the Edge of Certainty..., s. 145-260.

Feyerabend Paul K., Przeciw metodzie, przeł. Stefan Wiertlewski, Wydawnictwo SIEDMIORÓG, Wrocław 1996.

Feyerabend Paul K., „Reply to Criticism: Comments on Smart, Sellars and Putnam”, w: Feyerabend, Philosophical Papers. Vol. 1..., s. 104-131.

Feyerabend Paul K., „The Problem of the Existence of Theoretical Entities”, w: FeyerABEnd, Philosophical Papers. Vol. 3..., s. 16-49.

Godek Lidia, Musią Maciej i Woszczak Marek (red.), X Polski Zjazd Filozoficzny. Księga streszczeń, Wydawnictwo Naukowe Instytutu Filozofii UAM, Poznań 2015.

Hall A. Rupert, Rewolucja naukowa 1500-1800. Ksztaltowanie się nowożytnej postawy naukowej, przeł. Tadeusz Zembrzuski, Instytut Wydawniczy PAX, Warszawa 1966.

JoDKowski Kazimierz, „Antynaturalizm teorii inteligentnego projektu”, Roczniki Filozoficzne 2006, t. 54, nr 2, s. 63-76, https://tiny.pl/qzq86 (05.04.2019).

Jodkowski Kazimierz, „Filozofia nauki Paula K. Feyerabenda. Stadium umiarkowane”, Studia Filozoficzne 1979, nr 11 (168), s. 59-75.

JoDKowsкi Kazimierz (red.), Na czym polega racjonalność nauki?, Realizm. Racjonalność. Relatywizm, t. 7, Wydawnictwo UMCS, Lublin 1991.

JoDKowski Kazimierz, „Nienaukowy fundament nauki”, w: Zbigniew PIETRZAK (red.), Granice nauki, Lectiones \& Acroases Philosophicae 2013, t. VI, nr 1, s. 59-108.

JODKOwsKi Kazimierz, Metodologiczne aspekty kontrowersji ewolucjonizm kreacjonizm, Realizm. Racjonalność. Relatywizm, t. 35, Wydawnictwo UMCS, Lublin 1998. 
Jodkowski Kazimierz, Teza o niewspólmierności w ujęciu Thomasa S. Kuhna i Paula K. Feyerabenda, Realizm. Racjonalność. Relatywizm, t. 1, Wydawnictwo UMCS, Lublin 1984.

KAziBut Radosław, „Filozoficzna gramatyka praktyki laboratoryjnej Hasoka Changa a epistemiczny układ odniesienia Roberta Boyle'a", w: Godek, Musiaz i Woszczak (red.), X Polski Zjazd Filozoficzny..., s. 419-420.

Kazibut Radosław, „Potentia absoluta i epistemiczny układ odniesienia Roberta Boyle’a”, Filo-Sofija 2015, vol. 15, nr 30, s. 111-122, https://tiny.pl/gzntk (08.04.2019).

Kenyon Dean H., „Kreacjonistyczne ujęcie pochodzenia życia”, przeł. Kazimierz Jodkowski, w: Jodkowski, Metodologiczne aspekty..., s. 482-495.

KIERUL Jerzy, Izaak Newton. Bóg, światlo i świat, Oficyna Wydawnicza Quadrivium, Wrocław 1996.

KILIAN Krzysztof J., „Argumenty przeciwko naturalizmowi jako epistemicznemu układowi odniesienia", Filozoficzne Aspekty Genezy 2018, t. 15, s. 71-137, https://tiny.pl/tgj9g (19. 05.2019).

Kilian Krzysztof J., „Czym są epistemiczne układy odniesienia?”, Filozoficzne Aspekty Genezy 2017, t. 14, s. 191-236, https://tiny.pl/g86dn (19.05.2019).

KILIAN Krzysztof J., „Geneza idei epistemicznych układów odniesienia i ich odmiany”, Filozoficzne Aspekty Genezy 2017, t. 14, s. 137-190, https://tiny.pl/g2zqn (19.05.2019).

Meyer Stephen C., Signature in the Cell: DNA and the Evidence for Intelligent Design, HarperOne, New York 2009.

Monton Bradley, Seeking God in Science: An Atheist Defends Intelligent Design, Broadview Press, Canada 2009.

Musgrave Alan E., „Wpływ Einsteina na filozofię”, przeł. Kazimierz Jodkowski, w: JoDKOWSKI (red.), Na czym polega racjonalność nauki..., s. 79-105.

Newton Isaac, Matematyczne zasady filozofii przyrody, przeł. Jarosław Wawrzycki, Copernicus Center Press, Kraków 2011.

Provine William B., „Projekt? Tak! Ale czy inteligentny?”, przeł. Sławomir Piechaczek, Filozoficzne Aspekty Genezy 2005/2006, t. 2/3, s. 217-237, https://tiny.pl/xh8rs (08.04. 2019).

SAGAN Dariusz, „Jaki «artyficjalizm» stanowi epistemiczny układ odniesienia nauki”, Filozoficzne Aspekty Genezy 2018, s. 223-250, https://cutt.ly/AyRn4S (19.05.2019). 


\section{O jakim artyficjalizmie mówi się w ramach koncepcji epistemicznych układów odniesienia? Polemika z Dariuszem Saganem}

\section{Streszczenie}

Dariusz Sagan utrzymuje, że istnieją trzy możliwe epistemiczne układy odniesienia: naturalizm metodologiczny, nadnaturalizm i artyficjalizm. Pokazuję, że w polskim piśmiennictwie, odnosząc się do współczesnego pojmowania naukowości, wyróżniono więcej epistemicznych układów odniesienia. Ponadto ujęcie Sagana jest zbyt wąskie lub przedwczesne, ponieważ historia nauki nie została jeszcze zbadana pod tym względem.

W opinii Sagana Jodkowski i ja posługujemy się nazwą ,artyficjalizm” w sposób niejednoznaczny: traktowana jest ona jako epistemiczny układ odniesienia teorii inteligentnego projektu lub jako epistemiczny układ odniesienia nauki jako całości. Teoria inteligentnego projektu jest wzorcowym przykładem dopuszczania wyjaśnień artyficjalistycznych i stąd właśnie bierze się największa ilość odniesień do tej teorii jako przykładu akceptacji tego epistemicznego układu odniesienia. Zdaniem Sagana przypisywanie epistemicznym układom odniesienia tak zwanych „twardych jąder”, jak czynię to ja, jest błędem. Nie jest to błąd, tylko efekt rozpoznanego od dawna $\mathrm{w}$ filozofii nauki faktu występowania nierozerwalnego związku między akceptowanymi założeniami metodologicznymi i akceptowaną metafizyką.

Słowa kluczowe: Kazimierz Jodkowski, Dariusz Sagan, naturalizm metodologiczny, nadnaturalizm, artyficjalizm, epistemiczny układ odniesienia, teoria inteligentnego projektu, twarde jądro.

\section{What Kind of Artficialism Does the Concept of Epistemic Frameworks Apply To? A Polemic with Dariusz Sagan}

\section{Summary}

According to Dariusz Sagan, there are three possible epistemic frameworks: methodological naturalism, supernaturalism and artificialism. I aim to show that if we inspect the literature in Polish dealing with our contemporary understanding of science, we find that more epistemic frameworks have in fact been distinguished. Moreover, I argue that Sagan's approach is too narrow, or premature, in that the history of science has not yet been fully examined in regard to this.

According to Sagan, Jodkowski and I use the name "artificialism" in an ambiguous way: it is treated as an epistemic framework either for intelligent design theory or for science as a whole. The theory of intelligent design is a model example where artificialistic explanations are permitted, and so a maximal number of references to this theory is taken to itself be indicative of some sort of acceptance of this epistemic framework. Sagan also holds that ascribing so-called "hard cores" to epistemic frameworks, as I do, is a mistake. I, on the 
other hand, claim that that is not the case, as it is rather the effect of the fact - long-established in the philosophy of science - of the existence of an inseparable connection between the methodological assumptions we endorse and the metaphysical commitments we embrace.

Keywords: Kazimierz Jodkowski, Dariusz Sagan, methodological naturalism, supernaturalism, artificialism, epistemic framework, intelligent design theory, hard core. 